British politics

\section{Mrs Thatcher asks for decisiveness}

Mrs Margaret Thatcher, the British Prime Minister, remains convinced that the British research establishment would have no money problems if it managed its affairs properly. That was one of her opinions on the condition of British science to emerge from an interview last week

Formally, since the government in 1982 rejected the House of Lords' advice that there should be a part-time science minister on the grounds that it already had a scientist as a prime minister, hers is the desk on which the buck stops. How much time can she spare for it?

Coordinating departments straddling different interests are a mistake, she says, the Cabinet Office in the person of the Chief Scientific Adviser, Sir Robin ("Robin has been wonderful") Nicholson does whatever administrative coordination is needed, and her role is that of a catalyst. She lists the open seminar in September 1983 of scientists and industrialists (with a sprinkling of politicians) of which she was the chairman, and several more recent initiatives. She seems especially pleased about the meeting earlier this year at which $£ 42$ million was extracted from the spending departments to assist the growth of numbers of science and technology students in higher education.

One outcome of the 1983 seminar, at which she promised that innovations supported by the public purse would not be offered for exploitation exclusively to the National Research Development Corporation (now part of the British Technology Group) has now been realized. Mrs Thatcher cannot understand why there was so much red tape to clear away. She had wanted individual scientists to benefit more directly from their innovations, but had had to struggle to get her way.

What of the other promise, in 1983, that British defence establishments would be made more open, both to universities and industry? There is some confusion. The defence people have produced an unsatisfactory list of civil spin-off from military research and have been asked to revise it. Fair play, the defence people now have a kind of entrepreneurs' organization of their own.

Wealth creation is the name of the game. Mrs Thatcher says that scientists must appreciate that money for research can come only by the creation of wealth, for which they have a responsibility. But things are not as bad as they seem. She could name a dozen teams of academics pointing in the right direction (and, indeed, she embarks on a list).

On the research councils, she insists that people must be prepared to put their business schools? wishes in some order of priority. Complaints that first-class applications for research grants now often go unsupported are a sign that this is not happening. "People are not prepared to make decisions", she declares.

Mrs Thatcher is also offended at the way research councils administer their affairs. Applicants are asked to include three supporting opinions with their ap-

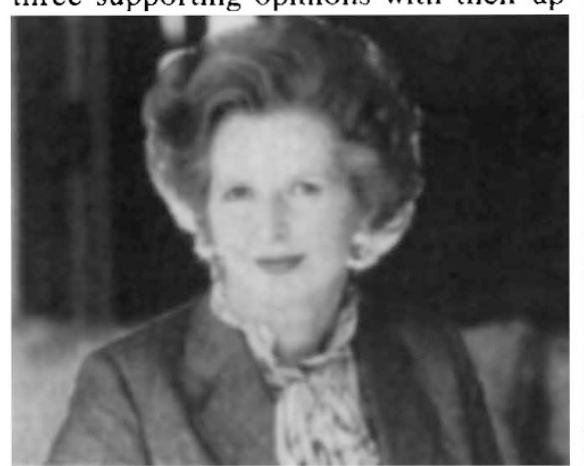

plications, but then "they send out for another three opinions", which is yet another sign that people are not prepared to take decisions. Why not instead give good institutions a quota of grants and let able professors decide who should get the money? Then the research councils could spend all their administration costs on research.

Reflectively, Mrs Thatcher wonders whether previous governments should not have been more "directional". During the university expansion of the 1960s, people may have been too conscious that the University Grants Committee is independent. The result was that too much of the expansion took place in the social sciences, not science and technology. And where else in the world does the government subsidize

Now she wants to see more centres of excellence in the universities. The trouble in the past has been that "we've not backed our judgement with money". This is what the University Grants Committee is now aiming at. (Sir Peter SwinnertonDyer, its chairman, is also "doing a very good job".) But Mrs Thatcher gives the impression that the recent green paper on higher education will not be her government's proudest achievement.

Mrs Thatcher also thinks it may have been a mistake to leave the judgement of what lines of research would be supported exclusively to the research councils. Earlier (as Secretary of State for Education and Science in the early 1970s), she had supported British high-energy physics. But now she wonders why the research councils are spending so much in this field when the same amount of money would allow them to do much more elsewhere.

She has little sympathy for the research councils now short of research funds because of having to persuade people to retire early. They have not organized themselves for flexibility. "The worst thing you can do in research" is to put able people in narrow institutes; then "they work on tramlines"

The problem, as she sees it, is that of persuading the research councils to spend their money wisely. They have a "bounden duty" to take responsibilty. Now, some people in the research establishment are beginning to do their duty. Sir Henry Chilver (director of the Cranfield Institute of Technology) is one, Dr John Ashworth (vice-chancellor of the University of Salford) is another. Mrs Thatcher contrasts these places, which are "creating jobs" with the other universities, in Manchester and Liverpool, where "we have these huge problems".

On the better exploitation of academic innovations, Mrs Thatcher agrees that industry may in the past have been at fault. People had to hawk their bright ideas around industry, often to no avail. But, she insists, the climate has now changed. It has taken a long time to get managers into a frame of mind to take decisions.

Mrs Thatcher praises the enterprise of the Victorian industrial revolution, acknowledges that one consequence may have been to divert large numbers of bright people into the administration of he old Empire, but says that, now, "the f articular combination of genius that we hive is not creating the wealth we need. G ve me just one MIT", she pleads.

Mrs Thatcher's impatience is understa. Idable, with the money supply once moie out of balance. What will happen in the nonths ahead to the British governmenı's research budget, and the recurrent grant for the universities, can only be a guess. But those who hope for extra funds probably hope in vain.

John Maddox

\section{Informatik stretched}

THE Westdeutsche Rektorenkonferenz (WRK), official organization of the West German university rectors, has asked for tighter restriction of student access to courses in information sciences (Informa$t i k)$. At their plenary meeting last week, the rectors pointed out that these new courses are overloaded by 200 per cent.

The president of WRK, Theodor Berchem, criticized the decision of the Länder (regional governments) to keep these courses open to general access. Part of the trouble is that the number of qualified professors for information sciences in West Germany is too small to cope with the demand. About 50 vacancies have not been filled, and for the planned 4,000 beginners (instead of 2,400 now), 100 additional positions for professors are needed.

Jürgen Neffe 